\title{
ESTUDO DOS NÍVEIS SÉRICOS DE PROGESTERONA E ESTRADIOL E DA ESTRUTURA DO TRATO GENITAL FEMININO DE QUEIXADA [Taiassu pecari (Link., 1795)]
}

\section{EVALUATION OF WHITE-LIPPED PECCARY'S [Taiassu pecari (Link., 1795)] PROGESTERON AND STRADIOL CERUM LEVELS AND FEMALE GENITAL TRACT STRUCTURE}

\author{
Paulo Rogério MANGINI \\ Orientador: Professor Dr. Pedro Ribas WERNER \\ Departamento de Medicina Veterinária
}

\begin{abstract}
RESUMO
A crescente preocupação com a diversidade biológica e a conservação das espécies animais nativas expande um enorme campo de pesquisa direcionado à solução dos problemas decorrentes do crescimento da população humana. O presente estudo avalia características morfológicas e histológicas dos ovários, tubas uterinas, útero, cérvice e vagina, além da concentração sérica de progesterona e estradiol de 15 fêmeas de queixada (Tayassu pecari), nascidas em criatório comercial, instalado na região de Quedas do Iguaçu - PR, BRASIL (52 $54^{\circ}$ W; $25^{\circ} 26^{\prime}$ S). Esta área se caracteriza pela transição entre Floresta Ombrófila Mista e Floresta Estacional Semidecidual. Todos os indivíduos foram abatidos e avaliados quanto a massa corporal, massa do aparelho reprodutor, comprimento e diâmetro ovariano, uterino, da cérvice, vagina e diâmetro das tubas uterinas. As amostras de sangue foram colhidas imediatamente antes do abate, sendo avaliadas as concentrações de progesterona e estradional, através de radioimunoensaio (RIE) de fase sólida. Os aparelhos reprodutores foram colhidos após o abate e avaliados histológica e macroscópicamente. As amostras colhidadas foram classificadas, conforme as caracteristicas histológicas, nas categorias de gestante $(n=1)$, folicular estral $(n=1)$, luteal inicial $(n=2)$ e luteal medial $(n=11)$. A massa corporal média dos animais em estudo foi de $26,23 \pm 3,62 \mathrm{~kg}$. A massa dos aparelhos reprodutores foi de $77,65 \pm 23,47 \mathrm{~kg}$. Os ovários direitos

apresentaram comprimento craniocaldal $14,32 \pm 2,15 \mathrm{~mm}$, dorsoventral $13,68 \pm 2,18 \mathrm{~mm}$ e laterolateral $9,68 \pm 1,60 \mathrm{~mm}$. Os ovários esquerdos apresentaram comprimento craniocaudal $12,81 \pm 1,45 \mathrm{~mm}$, dorsoventral $11,58 \pm 1,88 \mathrm{~mm}$ e laterolateral $8,58 \pm 1,16 \mathrm{~mm}$. O comprimento da cérvice foi de $30,89 \pm 12,34 \mathrm{~mm}$, o diâmetro externo foi de $18,62 \pm 4,16 \mathrm{~mm}$. O comprimento vaginal foi de $144,00 \pm 26,67 \mathrm{~mm}$, o diâmetro externo foi de $26,23 \pm 4,30 \mathrm{~mm}$. O comprimento e diâmetro uterinos variaram, significativamente conforme as categorias, entre $10 \mathrm{e}$ $34 \mathrm{~cm}$ de comprimento e 5,4 e $35 \mathrm{~cm}$ de diâmetro na porção média do corno uterino. Os valores hormonais séricos foram significativamente diferentes entre as categorias, variando entre 131,26 e $31,06 \mathrm{pg} / \mathrm{ml}$ para concentração de estradiol e 1,00 e $17,21 \mathrm{ng} / \mathrm{ml}$ para progesterona. Os diâmetros foliculares e dos corpos lúteos, na superfície dos ovários, não se apresentaram como formas eficientes de avaliação da fase do ciclo estral. As concentrações hormonais observadas foram compatíveis com os achados histológicos, comprovando a eficiência do método de análise hormonal e da avaliação histológica do aparelho reprodutor como formas de determinação da capacidade reprodutiva e da fase do ciclo estral de Tayassu pecari. Comprovou-se, ainda, a precocidade da espécie em cativeiro, reprodutivamente ativa a partir dos oito meses de idade.
\end{abstract}

\section{ABSTRACT}

Biological diversity and the preservation of native animal species has become a matter of increasing concern. This leads to an increase in research aiming at solving problems due to the growth of human population. This study evaluates morphologic and histological characteristics of ovaries, uterine tubes, uterus, cervix and vagina, as well as serum progesterone and estradiol levels in 15 female white-lipped peccaries (Tayassu pecari). All animals were born in a commercial farm in Quedas do Iguaçu, PR, BRAZIL ( $\left.52^{\circ} 54^{\prime} \mathrm{W} ; 2^{\circ} 26^{\prime} \mathrm{S}\right)$. The area is characterized by the transition from an Ombrofila Mixed Forest to a Semidecidual Stational Forest. All individuals were killed and corporal mass, reproductive tract mass, ovarian, uterine, cervical and vaginal length and diameter and uterine tube diameter were measured. Blood samples were collected immediately before killing and progesterone and estradiol levels were measured by solid phase radioimmunoassay (RIA). Reproductive tracts were sampled and histological structures were evaluated. Samples were classified, according to histological characteristics, in pregnant $(n=1)$, follicular $(n=1)$, early luteal $(n=2)$ and mid-luteal $(n=11)$ phases. The average corporal mass was $26.23 \pm 3.62 \mathrm{~kg}$. Average reproductive tract mass was $77.65 \pm 23.47 \mathrm{~kg}$. Right ovaries measures were as follows: craniocaudal length $14.32 \pm 2.15 \mathrm{~mm}$; dorsoventral length $13.68 \pm 2.18 \mathrm{~mm}$ and laterolateral length $9.68 \pm 1.60 \mathrm{~mm}$, while left ovaries measures were: craniocaudal length $12.81 \pm 1.45 \mathrm{~mm}$; dorsoventral length $11.58 \pm 1.88 \mathrm{~mm}$ and laterolateral length $8.58 \pm 1.16 \mathrm{~mm}$. The cervical length was $30.89 \pm 12.34 \mathrm{~mm}$ and the external diameter was $18.62 \pm 4.16 \mathrm{~mm}$. Vaginal length was $144.00 \pm 26.67 \mathrm{~mm}$ and the external diameter was $26.23 \pm 4.30 \mathrm{~mm}$. Uterine length and diameter varied significantly, according to the categories diameter in the median portion of uterine horn ranged from 5.4 to $35 \mathrm{~cm}$ and the length from 10.0 to $34.0 \mathrm{~cm}$. Hormonal levels were significantly different among the categories: estradiol levels ranged from 131.26 to $31.06 \mathrm{pg} / \mathrm{ml}$ and progesterone from 1.00 to $17.21 \mathrm{ng} / \mathrm{ml}$. Follicular and luteal bodies diameters, as seen on ovarian surface, did not prove to be efficient evaluation parameters in determining estral cycle phase. Hormonal concentrations were compatible with histolagical structures, which confirms the efficiency of both the RIA hormonal analysis method and also histological evaluation in determining Tayassu pecaris reproductive capacity and estral cycle phase. The species precocity while in captivity was also proven with reproductive capability starting at eight months of age. 